\title{
The sugar composition of fruits in the diet of spider monkeys (Ateles geoffroyi) in tropical humid forest in Costa Rica
}

\author{
Pablo Riba-Hernández*, Kathryn E. Stoner ${ }^{\dagger 1}$ and Peter W. Lucas ${ }^{\ddagger}$ \\ *Universidad de Costa Rica, Escuela de Biología, San Pedro, Costa Rica \\ †Centro de Investigaciones en Ecosistemas, Universidad Nacional Autónoma de México, Apartado Postal 27-3 (Xangari), Morelia, Michoacan, 48980 \\ Mexico \\ ‡Department of Anatomy, University of Hong Kong, 1st Floor Laboratory Block, 21 Sassoon Road, Hong Kong SAR, PR China \\ (Accepted 30 November 2002)
}

\begin{abstract}
Spider monkeys (Ateles geoffroyi) detect sucrose at a threshold lower than any primate yet tested and prefer sucrose to glucose or fructose in laboratory tests. This preferential selection of sucrose led to the hypothesis that such acute discrimination is related to a diet of sucrose-rich fruits. Furthermore, it has been suggested that fruit sugars may be related to distinct guilds of vertebrate seed-dispersers. The objectives of this study were: (1) to test if spider monkeys select sucrose-rich fruits both within and among plant species and (2) to test the hypothesis that sugar concentration is related to bird, bat or monkey seed-dispersal syndromes. Data were collected from one troop of spider monkeys in south-western Costa Rica. Interspecific comparison of ingested fruits shows that spider monkeys consumed species with significantly higher concentrations of glucose and fructose than sucrose. Similarly, at the intraspecific level, food-fruits had significantly more fructose and glucose than non-food fruits, but no difference was found for sucrose. The three different sugar types were not correlated with the importance of the species in the diet based on the amount of time they spent consuming each species. Although sucrose concentrations were significantly higher in primate-dispersed species compared with those dispersed by other vertebrates, soluble carbohydrates in primate-dispersed fruits were principally composed of glucose and fructose. Neither fructose nor glucose concentrations showed significant differences across the three categories of seed dispersal.
\end{abstract}

Key Words: Ateles geoffroyi, Costa Rica, frugivorous primates, fruit sugar composition, seed dispersal syndromes, spider monkeys, sugar preferences

\section{INTRODUCTION}

Soluble carbohydrates are a key biochemical reward in fruits, being reported to influence fruit choice by a wide variety of vertebrate frugivores, including birds, bats and primates (Herrera 1987, Janson et al. 1986, Johnson et al. 1985, Leighton 1993, Wendeln et al. 2000, Wrangham et al. 1991). More specifically, there is some evidence for selective preferences for particular sugars in frugivorous vertebrates. Passerine frugivorous birds prefer glucose and fructose to sucrose (Martínez del Río \& Restrepo 1993), while frugivorous bats prefer sucrose to fructose and glucose (Herrera M. 1999a, Herrera M. et al. 2000). With respect to primates, there is little detailed information available regarding specific sugar preferences. In fact, the sugar composition of primate fruits is largely unknown due to the historic reliance on total soluble carbohydrates to characterize pulp reward (Janson et al. 1986, Leighton 1993, Wrangham et al. 1991).

\footnotetext{
${ }^{1}$ Corresponding author. Email: kstoner@oikos.unam.mx
}

Recently, laboratory studies on spider monkeys (Ateles geoffroyi), baboons (Papio hamadryas anubis) and squirrel monkeys (Saimiri sciureus) have shown that simplestomached primates prefer sucrose to either fructose or glucose (Laska 1997, Laska et al. 1996, 1998, 1999a, b). In particular, one experiment on three spider monkeys showed an exceptionally low taste threshold for sucrose (3 $\mathrm{mM})$, compared to fructose $(15 \mathrm{mM})$ and glucose $(20$ $\mathrm{mM}$ ) (Laska et al. 1996). This sucrose threshold is the lowest for any primate yet tested, and it has been hypothesized that such acute discrimination may be related to their natural diet of fruits (Laska et al. 1996).

It has been suggested that vertebrate sugar preferences have evolutionary implications for fruit sugar composition as a means to attract seed dispersers (Baker et al. 1998, Herrera M. 1999a, Martínez del Río et al. 1992). In contrast, several studies have concluded that other factors override the effect of food composition in the natural diet. For example, Herrera M. (1999b) found that Neotropical frugivorous bats have different sugar preferences in experimental trials than the distribution of sugars in their 
natural diet. For some vertebrate species, other factors, such as the crop size of individual trees, have been recognized as important in determining which species of fruit are selected (Korine et al. 2000, Leighton 1993). In sum, it is unclear whether sugar concentrations are important in defining either fruit consumption by vertebrates or seed dispersal guilds.

The objectives of this study were: (1) to test if the diet of spider monkeys (Ateles geoffroyi) is dominated by sucrose-rich fruits, both within and among plant species and (2) to test the hypothesis that sugar concentration is related to seed dispersal syndromes. We predict concordance with laboratory tests: that spider monkeys will consume fruit species with higher concentrations of sucrose in relation to other sugars, and that, within individual trees, they will prefer fruits with higher sucrose concentration (i.e. sucrose concentration in food will be greater than non-food). Finally, we predict that species whose fruits are only consumed by monkeys will have a higher concentration of sucrose, in relation to other sugars, than species whose fruits are consumed by other vertebrates.

\section{METHODS}

\section{Study site}

The study was conducted at Punta Rio Claro Wildlife Refuge $\left(8^{\circ} 39^{\prime} \mathrm{N}, 83^{\circ} 44^{\prime} \mathrm{E}\right)$ on the Osa Peninsula in southwestern Costa Rica. The vegetation in this area is classified as tropical humid forest (Holdridge et al. 1971). The mean annual rainfall is $3000 \mathrm{~mm}$ in the lowlands and 4000 $\mathrm{mm}$ in the uplands, with a marked dry season from December to April (Hartshorn 1983). The refuge encompasses an area of 700 ha including 300 ha of mature forest, 200 ha of forest in advanced regeneration or mature forest that has only experienced selective logging, and the rest being open areas or pastures.

This area has a relatively intact fauna being found approximately $5 \mathrm{~km}$ from Corcovado National Park, which encompasses a protected area of 41788 ha (Franke 1993). Other vertebrates in the region that consume fruit, at least seasonally, include mantled howler monkeys (Alouatta palliata), white-faced capuchin monkeys (Cebus capuchinus), coatimundis (Nasua narica), kinkajous (Potos flavus), and approximately 20 species of frugivorous bats (Riba \& Stoner, pers. obs. based on unpublished mist-net data). Squirrel monkeys (Saimirii oerstedii) and Baird's tapir (Tapirus bairdii) are no longer found in the refuge. However, both species are common in some areas of Corcovado and presumably were previously present at this site. At least 63 species of birds are found in the region that consume fruits, including the chestnutmandibled toucan (Ramphastos swainsonii) and the scarlet macaw (Ara macao) (Stiles \& Skutch 1989).

\section{Data collection on foraging}

The foraging behaviour of one troop of A. geoffroyi containing 30 individuals was studied from May 1999 through May 2000. Data were collected using 2-min focal animal observations to obtain information on fruit consumption (Altmann 1974). All individuals were identified to sex and age-class and focal animals were randomly changed after each 2-min observation. Only data from adults were included in the analysis because of the infrequent observations on juveniles. Data were collected $2 \mathrm{~d}$ per wk from 6h00-18h00.

Fruits were considered consumed (food) when monkeys bit into the fruit more than twice and swallowed the pulp or when the entire fruit was swallowed. Samples of food fruits were collected when monkeys accidentally dropped fruits or fruit pieces before consuming the entire fruit. Non-food fruits were the closest fruits on the branch to the fruit that was eaten. Samples of non-food fruits were obtained when monkeys were foraging and broke off a piece of the branch. When non-food fruit samples could not be obtained while collecting foraging data, we returned to the same tree the following day and used a telescopic tree pruner to collect samples. The importance of each fruit species in the diet was calculated as the percentage of feeding time spent on each fruit species with respect to time spent feeding on all fruit species.

Fruit samples were placed in separate plastic bags and extracts from pulp were prepared on the day of collection. We used a tissue homogenizer (Tissue-Tearor, Dremel, Racine, WISC, USA) to extract $0.1 \mathrm{~g}$ of fruit pulp in $5 \mathrm{ml}$ of $50 \%$ methanol (Lucas et al. 2001). After homogenization, pulp material was stored for $2 \mathrm{~h}$ to allow sedimentation and then filtered and stored in a refrigerator at $4{ }^{\circ} \mathrm{C}$.

To determine the role of sugars in targetting particular frugivorous vertebrates, we classified each species of fruit consumed by spider monkeys into one of three categories: (1) principally consumed by primates, (2) principally consumed by birds and primates and (3) principally consumed by birds, primates, and bats. These data were compiled using personal observations and the published literature about seed dispersal (Estrada et al. 1984, Handley et al. 1991, Levey et al. 1994, Palmeirim et al. 1989, Quesada et al. 1997, Skutch 1980, Worthington 1990). Category 1 was only recognized when no observations of other consumers were made during our study and there were no published records of the species being consumed by other vertebrates. Other vertebrates may have consumed categories 2 and 3 , but the main consumers were birds and primates, and birds, primates and bats, respectively.

\section{Laboratory method}

Sugar concentration in fruit pulp was determined using a Dionex HPLC system (Dionex Corp. Sunnyvale, Cali- 
fornia, USA) fitted with a Carbo Pac PA- 1 column $(4 \times$ $250 \mathrm{~mm}$ ), and a $10 \mu \mathrm{l}$ sample loop with $4 \mathrm{mM} \mathrm{NaOH}$ isocratic solution $\left(1 \mathrm{ml} \mathrm{min}{ }^{-1}\right)$. An ED40 electrochemical detector fitted with a pulsed amperometric cell was used (Ko et al. 1998, Lee 1990). Sucrose, glucose and fructose were used as standards to calibrate the output. Other sugar standards were only used when unidentified sugars in the extracts appeared in appreciable concentrations. The only example of this was arabinose, present in Lacmellea panamensis pulp. To obtain the best correspondence with laboratory information and the mechanism of taste sensations, we recorded sugar concentrations in terms of molarity.

\section{Statistical analysis}

To test the hypothesis that spider monkeys consume sucrose-rich fruits, we used an ANOVA to compare the concentration of sucrose, glucose and fructose in food fruits, then we used a Tukey test to determine which pairs of sugar concentrations were significantly different from each other. Results on sugar concentration were logtransformed prior to analysis to normalize the data. To further evaluate if spider monkeys consume sucrose-rich fruits, paired t-tests were used to compare sugar concentrations of the three different sugar types in food vs. nonfood fruits for individual trees. Spearman rank correlation coefficients were used to evaluate if the concentration of different sugars was correlated with the importance of the species in the diet.

To test the hypothesis that the concentration of sucrose, fructose and glucose depends upon the dispersal syndrome, ANOVA tests were used to compare sugar concentration of the different sugar types across and within dispersal syndromes. Finally, to specifically test the hypothesis of Baker et al. (1998) that the ratio of sugars is important for different vertebrate dispersers we compared the ratio of glucose + fructose/sucrose among dispersal syndromes using a Kruskal-Wallis test and then used Mann-Whitney tests for pairwise comparisons to determine which pairs were significantly different from each other. Systat (1998) was used for all statistical comparisons.

\section{RESULTS}

Foraging data were collected over $64 \mathrm{~d}$ ( $24 \mathrm{~d}$ in the dry season and 42 in the rainy season) for a total of 460 contact hours. Observations were made for approximately $7 \mathrm{~h}$ per day (range 4-11 h). Fruits were consumed from 63 species with 32 of these species accounting for $80 \%$ of the time that spider monkeys dedicated to fruit consumption. The percentage of time devoted to feeding on each fruit species was calculated from a total of $1490 \mathrm{~min}$ of focal animal observations (745 events) (Table 1). Six species did not contain sucrose, while glucose and fructose were present in all consumed fruits (Table 1). Species consumed contained a relatively greater amount of monosaccharides: $45 \% \pm 17.5 \%$ of total sugars was glucose, $47 \% \pm 19.3 \%$ fructose, and only $7.7 \% \pm 12.4 \%$ was sucrose. Sixty-two per cent of the species consumed had ratios that were approximately 1:1 for glucose and fructose, while $19 \%$ had more fructose than glucose and $19 \%$ had more glucose than fructose (Table 1).

The concentration of each sugar type, within the species consumed by spider monkeys, was significantly different $\left(\mathrm{F}_{(2,72)}=34.5, \mathrm{P}<0.0001\right)$, with sucrose at lower concentrations than glucose and fructose (Tukey test, $\mathrm{P}<0.0001$; $\mathrm{P}<0.001$, respectively). However, the concentration of these two monosaccharides was not significantly different (Tukey test, $\mathrm{P}=0.982$ ). Similarly, the comparison within species showed that food fruits had significantly more fructose $(\mathrm{t}=1.16, \mathrm{P}<0.05$, df $=12)$ and glucose $(\mathrm{t}=2.87, \mathrm{P}<0.01, \mathrm{df}=12)$ than non-food fruits, but no difference was found for sucrose concentration $(\mathrm{t}=2.16$, $\mathrm{P}>0.05$, df = 12; Figure 1).

Total sugar concentration was not correlated with the importance of fruit species in the $\operatorname{diet}(\mathrm{r}=0.112, \mathrm{P}>0.05$, $\mathrm{N}=27$ ). Similarly, neither glucose concentration $(\mathrm{r}=0.212, \mathrm{P}>0.05, \mathrm{~N}=27)$, fructose concentration ( $\mathrm{r}=0.179, \mathrm{P}>0.05, \mathrm{~N}=27$ ) nor sucrose concentration $(\mathrm{r}=0.107, \mathrm{P}>0.05, \mathrm{~N}=27)$ was correlated with the importance of the species in the diet. Approximately $48 \%$ of spider monkeys' foraging time on fruits (12 species) was concentrated on species that are principally dispersed by primates in this area. Similarly, they spent $43 \%$ of their time (13 species) foraging on fruit species that are principally dispersed by primates and birds, while they only spent $9.1 \%$ of their foraging time (seven species) on fruits dispersed by primates, birds and bats (Table 1). Primatedispersed fruits had a significantly higher concentration of sucrose $\left(\mathrm{F}_{2,22)}=13.2, \mathrm{P}<0.005\right)$ than fruits dispersed by

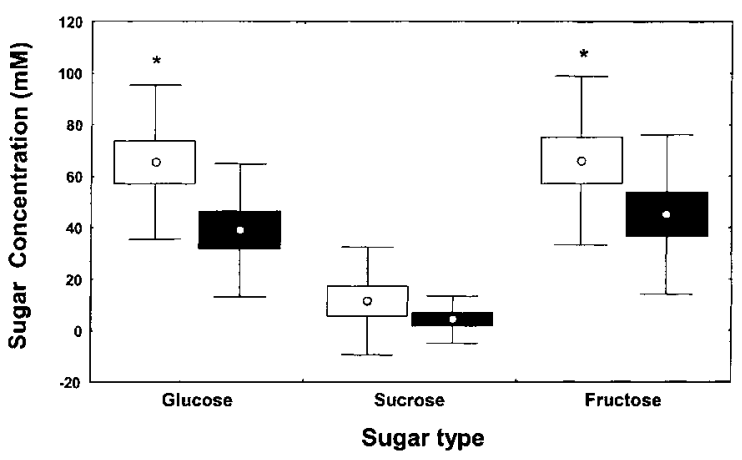

Figure 1. Comparison of glucose, fructose and sucrose concentration $(\mathrm{mM})$ of fruit pulp in food (open white boxes) and non-food (solid black boxes) fruits used by spider monkeys in a tropical humid forest. Boxes represent means \pm standard error; whiskers represent means \pm standard deviation, and squares represent mean values $(\mathrm{n}=13$ species, $* \mathrm{P}<0.05$, paired t-tests). 
Table 1. Soluble carbohydrate concentration in fruit pulp of species consumed by spider monkeys, per cent feeding time on each species in the fruit diet, and seed dispersal mode for each species (B: bird, P: primate, C: chiroptera). Sugar concentrations are mean \pm standard deviation

\begin{tabular}{|c|c|c|c|c|c|c|c|}
\hline Family & Species & $\begin{array}{c}\mathrm{N} \\
\text { fruits }\end{array}$ & $\begin{array}{l}\text { Glucose } \\
(\mathrm{mM})\end{array}$ & $\begin{array}{l}\text { Sucrose } \\
(\mathrm{mM})\end{array}$ & $\begin{array}{l}\text { Fructose } \\
(\mathrm{mM})\end{array}$ & $\begin{array}{l}\text { Per cent } \\
\text { feeding } \\
\text { time }\end{array}$ & $\begin{array}{l}\text { Principal } \\
\text { dispersal } \\
\text { agent }\end{array}$ \\
\hline Anacardiaceae & Spondias mombin $\mathrm{L}$. & 18 & $113.7 \pm 24.4$ & $0.3 \pm 0.77$ & $114.9 \pm 28.7$ & 2.3 & $\mathrm{~B}^{1}, \mathrm{P}^{2}, \mathrm{C}^{2,4}$ \\
\hline Apocynaceae & $\begin{array}{l}\text { Lacmellea panamensis } \\
\text { (Woodson) Markgr. }\end{array}$ & 7 & $74.3 \pm 23.8$ & $4.5 \pm 8.2$ & $112 \pm 35.5$ & 1.8 & $\mathrm{P}^{1}$ \\
\hline Araceae & Anthurium sp. & 1 & 210.8 & 0 & 24.84 & 0.4 & $\mathrm{~B}^{2}, \mathrm{P}^{1}$ \\
\hline Araliaceae & $\begin{array}{l}\text { Dendropanax arboreus (L.) } \\
\text { Decne. \& Planch. }\end{array}$ & 5 & $78.4 \pm 54.4$ & $2.1 \pm 2.2$ & $25.1 \pm 112.7$ & 1.2 & $\mathrm{~B}^{5}, \mathrm{P}^{6}$ \\
\hline Caricaceae & Jacaratia spinosa (Aubl.) DC. & 1 & 79.4 & 17.4 & 24.1 & 1.5 & $\mathrm{~B}^{1}, \mathrm{P}^{1}$ \\
\hline \multirow[t]{2}{*}{ Cecropiaceae } & Cecropia obtusifolia Bertol. & 2 & $121.4 \pm 23.1$ & 0 & $87.1 \pm 20.1$ & 0.3 & $\mathrm{~B}^{7}, \mathrm{P}^{7}, \mathrm{C}^{3}$ \\
\hline & Pourouma bicolor Mart. & 1 & 9.0 & 1.9 & 100.4 & 0.7 & $\mathrm{~B}^{1}, \mathrm{P}^{1}$ \\
\hline Chrysobalanaceae & Licania sp. & 4 & $87.2 \pm 84.5$ & $0.7 \pm 1.5$ & $101.4 \pm 100.5$ & 0.4 & $\mathrm{~B}^{3}, \mathrm{P}^{1}, \mathrm{C}^{3}$ \\
\hline \multirow[t]{2}{*}{ Clusiaceae } & Clusia rosea Jacq. & 1 & 4.9 & 0.2 & 4.4 & 1.2 & $\mathrm{~B}^{8}, \mathrm{P}^{1}$ \\
\hline & $\begin{array}{l}\text { Garcinia madruno (Kunth) } \\
\text { Hammel }\end{array}$ & 2 & $0.4 \pm 0.1$ & $0.2 \pm 0.8$ & $59.5 \pm 82.7$ & 0.4 & $\mathrm{P}^{1}$ \\
\hline \multirow[t]{2}{*}{ Convolvulaceae } & Unidentified species 1 & 7 & $19.7 \pm 25.8$ & $25.1 \pm 33.3$ & $24.2 \pm 35.9$ & 1.1 & $\mathrm{P}^{1}$ \\
\hline & Unidentified species 2 & 18 & $83.4 \pm 38.5$ & $80.1 \pm 25.4$ & $81.5 \pm 53.2$ & 1.4 & $\mathrm{P}^{1}$ \\
\hline Humiriaceae & Humiriastrum diguense Cuatrec. & 3 & $19.7 \pm 9.5$ & $44 \pm 5.5$ & $19.4 \pm 12.1$ & 1.4 & $\mathrm{P}^{1}$ \\
\hline Malpighiaceae & Byrsonima crispa A. Juss. & 2 & $77.2 \pm 19.8$ & $4.4 \pm 7.8$ & $75.3 \pm 20.7$ & 2.4 & $\mathrm{~B}^{5}, \mathrm{P}^{1}$ \\
\hline Marcgraviaceae & $\begin{array}{l}\text { Souroubea vallicola Woodson } \\
\text { ex de Roon }\end{array}$ & 14 & $27.2 \pm 39.9$ & $2.1 \pm 2.8$ & $33.4 \pm 47.2$ & 1.8 & $\mathrm{~B}^{8}, \mathrm{P}^{1}$ \\
\hline Melastomataceae & Unidentified species 3 & 3 & $79.1 \pm 23.2$ & $2.9 \pm 11.9$ & $80.3 \pm 27.5$ & 0.2 & $\mathrm{~B}^{2}, \mathrm{P}^{1}$ \\
\hline Mimosaceae & Inga $\mathrm{sp}$. & 1 & 59.7 & 49.2 & 98.8 & 3.8 & $\mathrm{P}^{1}$ \\
\hline \multirow[t]{3}{*}{ Moraceae } & Brosimum costaricanum Liebm. & 4 & $59.3 \pm 28.7$ & 0 & $23.1 \pm 32$ & 1.2 & $\mathrm{~B}, \mathrm{P}^{1,3}, \mathrm{C}^{3}$ \\
\hline & Ficus colubrinae Standl. & 3 & $77.3 \pm 59.2$ & 0 & $20.2 \pm 42.2$ & 0.2 & $\mathrm{~B}^{9}, \mathrm{P}^{7}, \mathrm{C}^{3}$ \\
\hline & $\begin{array}{l}\text { Pseudolmedia oxyphyllaria } \\
\text { Donn. Sm. }\end{array}$ & 3 & $99.1 \pm 44.1$ & 0 & $99.3 \pm 44.0$ & 1.3 & $\mathrm{~B}^{3}, \mathrm{P}^{3}, \mathrm{C}^{3}$ \\
\hline Myristicaceae & Virola sebifera Aubl. & 13 & $20.2 \pm 21.5$ & $0.2 \pm 0.5$ & $12.4 \pm 17.3$ & 2.3 & $\mathrm{~B}^{8}, \mathrm{P}^{1}$ \\
\hline \multirow[t]{2}{*}{ Rubiaceae } & $\begin{array}{l}\text { Posoqueria latifolia (Rudge) } \\
\text { Roem. \& Schult. }\end{array}$ & 3 & $125.0 \pm 28.4$ & $8.4 \pm 14.2$ & $222.7 \pm 21.4$ & 0.9 & $\mathrm{P}^{1}$ \\
\hline & Unidentified species 4 & 3 & $217.4 \pm 54.2$ & 0 & $245.4 \pm 71.7$ & 0.3 & $\mathrm{~B}^{1}, \mathrm{P}^{1}$ \\
\hline Sapindaceae & $\begin{array}{l}\text { Dilodendron costaricense } \\
\text { (Radlk.) A.H. Gentry \& } \\
\text { Steyerm. }\end{array}$ & 5 & $112.7 \pm 47.2$ & $98.2 \pm 25.1$ & $32.7 \pm 32.3$ & 0.5 & $\mathrm{P}^{1}$ \\
\hline \multirow[t]{2}{*}{ Sapotaceae } & Pouteria torta (Mart.) Radlk. & 3 & $70.45 \pm 78.3$ & $100.2 \pm 72.3$ & $74.1 \pm 72.8$ & 1.2 & $\mathrm{P}^{1}$ \\
\hline & $\begin{array}{l}\text { Elaeoluma glabrescens (Mart. \& } \\
\text { Eichler) Aubrév. }\end{array}$ & 2 & $99.3 \pm 39.5$ & $23.1 \pm 12.4$ & $101.1 \pm 42.3$ & 22.5 & $\mathrm{P}^{1}$ \\
\hline Tiliaceae & $\begin{array}{l}\text { Mortoniodendron anisophyllum } \\
\text { (Standl.) Standl \& Steyerm. }\end{array}$ & 9 & $328.2 \pm 110.5$ & 0 & $432.1 \pm 82.2$ & 23.7 & $\mathrm{~B}^{1}, \mathrm{P}^{1}$ \\
\hline
\end{tabular}

Source reference for dispersal mode: present study ${ }^{1}$, Worthington $1990^{2}$, Estrada et al. $1984^{3}$, Handley et al. $1991^{4}$, Quesada et al. $1997^{5}$, Hladik \& Hladik $1969^{6}$, Levey et al. $1994^{7}$, Skutch $1980^{8}$, Palmeirim et al. $1989^{9}$.

other vertebrates; however, sucrose concentration was not significantly different from the concentration of glucose and fructose $\left(\mathrm{F}_{(2,27)}=3.1, \mathrm{P}>0.05\right)$ in this group of fruit. In fact, monosaccharides dominated sugar concentration in primate-dispersed fruits $(35.7 \% \pm 14.9 \%$ of glucose and $46.6 \% \pm 24.1 \%$ of fructose, but only $17.7 \% \pm 15.4 \%$ of sucrose; Figure 2). Neither fructose $\left(\mathrm{F}_{(2,22)}=0.6, \mathrm{P}=\right.$ $0.541)$ nor glucose $\left(\mathrm{F}_{(2,22)}=0.5, \mathrm{P}=0.626\right)$ showed significant differences across the three categories of seed dispersal; however fructose and glucose were found at higher concentrations than sucrose in species dispersed by birds and primates $\left(\mathrm{F}_{(2,30)}=29.2, \mathrm{P}<0.0001\right)$ and species dispersed by birds, primates and bats $\left(\mathrm{F}_{(2,9)}=760, \mathrm{P}<\right.$ 0.0001; Figure 2). The ratio of glucose + fructose/sucrose among dispersal syndromes was significantly different (Kruskal-Wallis $\mathrm{H}=7.8, \mathrm{P}<0.05$, Table 2) with pairwise comparisons showing that primate-dispersed species had a significantly lower ratio than species dispersed by birds, bats and primates (Table 3 ).

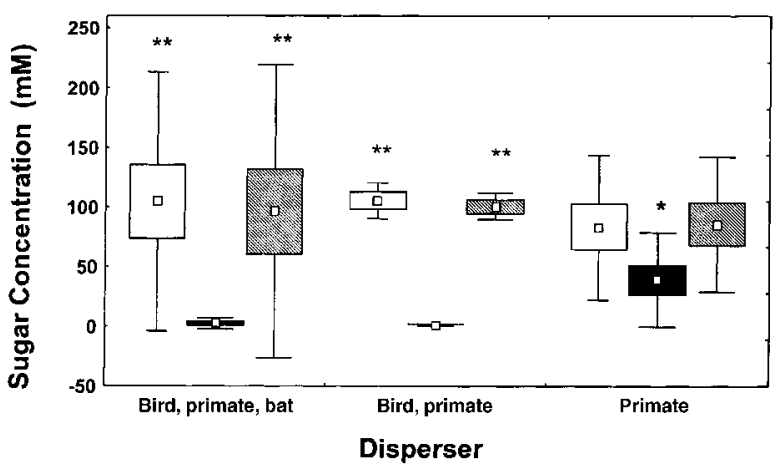

Figure 2. Comparison of glucose, fructose and sucrose concentration $(\mathrm{mM})$ in fruits consumed by spider monkeys in a tropical humid forest classified by dispersal mode. Classification is based on observation from the present study and the literature. Boxes represent means $< \pm->$ standard error; whiskers represent means \pm standard deviation, and circles represent mean values. White open boxes represents glucose values, black solid box represents sucrose values, and diagonal-lined boxes represents fructose values $(\mathrm{n}=26$ species; $* \mathrm{P}<0.05)$. 
Table 2. Mean values of the ratio of glucose + fructose/sucrose in fruit pulp of fruits consumed by spider monkeys classified by dispersal mode (data from Table 1). Kruskal-Wallis $\mathrm{H}=7.8, \mathrm{P}<0.05$.

\begin{tabular}{lcc}
\hline Dispersal mode & $\mathrm{N}^{1}$ fruits & $\begin{array}{c}\text { Glucose }+ \text { fructose/sucrose } \\
(\text { Mean } \pm \mathrm{SD})\end{array}$ \\
\hline Bird, primate, bat & 2 & $525.8 \pm 443$ \\
Primate & 10 & $24.05 \pm 34$ \\
Bird, primate & 8 & $92.05 \pm 140$ \\
\hline
\end{tabular}

${ }^{1}$ The number of fruits was reduced due to the absence of sucrose in fruit pulp of some species (see Table 1).

Table 3. Results of pair-wise comparisons of the ratio of glucose + fructose/sucrose between dispersal syndromes using the Mann-Whitney Test $(* \mathrm{P}<0.05)$

\begin{tabular}{lcc}
\hline Dispersal mode & Bird, primate, bat & Bird, primate \\
\hline Primate & $0.03^{*}$ & 0.05 \\
Bird, primate & 0.07 & \\
\hline
\end{tabular}

\section{DISCUSSION}

Laska et al. (1996, 1998) have hypothesized that frugivorous primates use sweetness as a criterion for food choice. Sucrose may be especially important in the fruit choices of A. geoffroyi because this species prefers sucrose over glucose and fructose in laboratory trials, and detects sucrose at much lower concentrations than these other sugars (Laska et al. 1996, 1998). However, we found no evidence that spider monkeys consume sucrose-rich fruits in their natural diets. In fact, fruits dominated by monosaccharides predominated in the natural diet of $A$. geoffroyi (Figure 1). We should mention that time spent feeding on a particular fruit species does not necessarily reflect the amount ingested per unit time, as handling time of food items varies between species and over time (Altmann 1998).

Our observation that spider monkeys do not seek out sucrose-rich fruits is consistent with results obtained for neotropical frugivorous bats. In a laboratory study using the frugivorous bats, Artibeus jamaicensis and Sturnira lilium, Herrera M. (1999a) expected that these species would show preferences for the most common sugars in their natural diet (glucose and fructose). However, they showed preferences for sucrose, suggesting that other factors influence preference for sugar in neotropical bats that override the effect of food composition in their natural diet. This also may be the case of spider monkeys, which have shown preference for food with higher energy content and minerals in laboratory trials, but not for higher concentration of individual sugars (Laska et al. 2000).

The explanation for this may lie in whether sugars are distinguishable. Breslin et al. (1996) have suggested that sucrose, fructose and glucose are all probably detected by the same receptor in humans. These are thus qualitatively indistinguishable, perceived differences relating only to the intensity of receptor binding. They note, however, that the sweetness of maltose deviates from that of other sugars at high concentrations and that its detection must also involve some other mechanism. Rats can taste oligosaccharides, derived from starch, contained in a commercial corn starch syrup called Polycose (Sclafani 1991). Laska et al. (2001) have recently investigated this in four primates, the pigtailed macaque (Macaca nemestrina), the olive baboon (Papio anubis), a species of squirrel monkey (Saimiri sciureus) and spider monkey (Ateles geoffroyi), showing that macaques prefer these oligosaccharides and maltose to simple sugars.

In contrast to Breslin et al.'s (1996) findings, recent research on taste receptors in mice has shown that one 'broadly tuned' sweet receptor, involving T1R2 and T1R3 gene products, responds strongly and evenly to sucrose and fructose, but not at all to glucose or maltose (Nelson et al. 2001). The equivalent study for human taste cells has yet to be performed. They might respond differently because genes coding for chemosensory $\mathrm{G}$ proteins are very variable between species (Nelson et al. 2001). The most parsimonious suggestion at present is to suggest that glucose, galactose, maltose and some oligosaccharides are all detected by a separate sweetness receptor from that which detects sucrose and fructose. However, it seems wiser at this stage not to generalize and to treat each sugar separately.

Evolutionary patterns of seed dispersal by other vertebrates may partially explain the dominance of glucose and fructose in the natural diet of spider monkeys. In passerine frugivorous birds, avoidance of sucrose has been partially explained because many species lack sucrase, the enzyme responsible for hydrolysing sucrose into glucose and fructose (Martínez del Río \& Restrepo 1993). Interestingly, even birds that have a significant amount of sucrase avoid sucrose (Martínez del Río \& Restrepo 1993). It appears that the fast passage rate of food constrains efficient hydrolysis of sucrose, thus causing many species of birds to avoid consuming this disaccharide, and increase the consumption of monosaccharides that can be assimilated quickly (Martínez del Río \& Karasov 1990).

Although it is unlikely that these two physiological constraints are present in spider monkeys, it is possible that the physiological constraints of frugivorous passerine birds for metabolizing sucrose may have contributed to the dominance of monosaccharides in fruits in early angiosperms (Baker et al. 1998). As a consequence, the fruit diet of A. geoffroyi might have evolved in a predominantly bird-fruit dispersal system dominated by monosaccharides. Over time, some fruits may have increased husk protection as a defence against other selective pressures such as seed depredation by insect herbivores (Herrera 1982). These fruits, originally principally consumed by birds, would have been more difficult for birds to manipulate and thus these species would have been targeted by other animals for seed dispersal. As the change from 
monosaccharides to sucrose-rich fruits may respond quickly to natural selection (Ko et al. 1998), these newly protected fruits likely produced sucrose in their pulp to target primates and other mammals that possess bony jaws, complex teeth and manipulative tongues that facilitate fruit processing (Janson 1983). This possible scenario could explain why primate-dispersed fruits had a significantly higher concentration of sucrose than fructose or glucose, in spite of the fact that they were principally dominated by glucose and fructose.

We suggest that monosaccharides in fruits may play an important role in overall attractiveness, not only to spider monkeys, but also to other frugivores in the Neotropics. Maintaining the strategy of attractiveness by monosaccharides may have benefits, both for the nutritional needs of frugivores and plant reproduction. In the case of frugivores, consuming sugar-rich fruits allows them to exploit a readily usable energy source that can be either used directly or stored as fats. Glucose and fructose are readily absorbed and can be metabolized directly. Furthermore, since glucose and fructose are rapidly absorbed in the small intestine, this allows frugivores to pass bulky materials like seeds more rapidly, allowing them to increase energy intake (Milton 1981). From the plant's point of view, sugar-rich fruits increase fruit removal from parent trees by being attractive to a variety of potential dispersers such as birds, primates and other mammals (Wheelwright \& Orians 1982). Moreover, due to the rapid assimilation of these sugars, quicker seed passage rates through frugivores' intestines reduce seed damage by digestive processes.

The presence of low sensitivity thresholds for sugars and especially for sucrose in spider monkeys may represent a response to the high seasonality and unpredictable production of fruits in the Neotropics (Frankie et al. 1974, Newstrom et al. 1994). Low sensitivity thresholds broaden the perception of potential foods in a changing environment by intensifying responses to foods of lower sugar concentration. Accordingly, subsistence human populations living in the dry, seasonal habitats of Africa (where fruits are less available) have a much lower detection threshold for sucrose and glucose (but not fructose) than those living in rain forests (Hladik \& Simmen 1996). Laboratory studies have shown that lean mouse lemurs (Microcebus murinus) have a lower threshold for fructose (28-45 mM) than obese mouse lemurs (77-105 mM) (Hellekant et al. 1993), indicating that behavioural responses are plastic enough to respond to physiological conditions. In fact, some birds are able to compensate behaviourally for dietary changes in sugar concentrations (Witmer 1998). The adaptive significance of such acute sensory and behavioural mechanisms is clear given that even soluble sugars themselves may fluctuate in an unpredictable manner (Simmen \& Sabatier 1996).

Since primates are more generalized feeders with respect to fruit syndromes than some other vertebrates (Janson 1983, present study) and the change from monosaccharides to sucrose-rich fruits may respond quickly to natural selection (Ko et al. 1998), maintaining low sugar thresholds is particularly important for a specialized frugivorous primate to facilitate the recognition of potential food items in periods of low resource availability. Future studies should evaluate the distribution of sugars in all available fruits with regard to seed dispersal syndrome.

\section{ACKNOWLEDGEMENTS}

We thank Silvia Solis Madrigal and Wanda Petersen Pereira for their invaluable field assistance and Mabel Ip and Lawrence Ramsden for HPLC sugars analysis. We are grateful to the Research Grants Council of Hong Kong, National Geographic Society, and Marenco Beach and Rainforest lodge for providing financial assistance for this research. We thank German Llano, Clara Fernández and Franklin Araya for allowing us to work on their property when monkeys moved out of the wildlife refuge. We thank Nathaniel Dominy, Nayuta Yamashita, and three anonymous reviewers for helpful comments on a previous draft of this manuscript. This manuscript is dedicated to the memory of our friend Eduardo Miranda.

\section{LITERATURE CITED}

ALTMANN, J. 1974. Observational study of behaviour: sampling methods. Behaviour 49:227-267.

ALTMANN, S. A. 1998. Foraging for survival: yearling baboons in Africa. University of Chicago Press, Chicago. 610 pp.

BAKER, H. G., BAKER, I. \& HODGES, S. A. 1998. Sugar composition of nectar and fruits consumed by birds and bats in the tropics and subtropics. Biotropica 30:559-586.

BRESLIN, P. A. S., BEAUCHAMP, G. K. \& PUGH, E. N. 1996. Monogeusia for fructose, glucose, sucrose, and maltose. Perception and Psychophysics 58:327-341.

ESTRADA, A., COATES-ESTRADA, R., VÁZQUES-YANEZ, C. \& OROZCO-SEGOVIA, A. 1984. Comparison of frugivory by howling monkeys (Alouatta palliata) and bats (Artibeus jamaicensis) in the tropical rain forest of Los Tuxtlas, Mexico. American Journal of Primatology 7:3-13.

FRANKE, J. 1993. Costa Rica's national parks and preserves: a visitor's guide. The Muntaineers, Seattle, Washington. 223 pp.

FRANKIE, G. W., BAKER, H. G. \& OPLER, P. A. 1974. Comparative phenological studies of trees in tropical wet and dry forest in the lowlands of Costa Rica. Journal of Ecology 62:881-919.

HANDLEY, C. O., GARDNER, A. L. \& WILSON, D. E. 1991. Food habits. Pp. 141-146 in Handley, C. O., Wilson, D. E. \& Gardner, A. L. (eds). Demography and natural history of the common fruit bat, Artibeus jamaicensis, on Barro Colorado Island, Panama. Smithsonian Institution Press, Washington, DC.

HARTSHORN, G. S. 1983. Plants: introduction. Pp. 118-157 in Janzen, 
D. H. (ed.). Costa Rican natural history. University of Chicago Press, Chicago.

HELLEKANT, G., HLADIK, C. M., DENNYS, V., SIMMEN, B., ROBERTS, T. W. \& GLASSER, D. 1993. On the relationship between sweet taste and seasonal body weight changes in a primate (Microcebus murinus). Chemical Senses 18:27-33.

HERRERA, C. 1982. Defenses of ripe fruit from pests: its significance in relation to plant-disperser interaction. American Naturalist 120: 218-241.

HERRERA, C. M. 1987. Vertebrate-dispersed plants of the Iberian Peninsula: a study of fruit characteristics. Ecological Monographs 57:305-331.

HERRERA M., L. G. 1999a. Sugar composition of fruit and nectar and preferences of bats: causes and consequences. Acta Chiropterologica 1:201-208.

HERRERA M., L. G. 1999b. Preferences for different sugars in Neotropical nectarivorous and frugivorous bats. Journal of Mammalogy 80:683-688.

HERRERA M., L. G., LEBLANC, D. \& NASSAR, J. 2000. Sugar discrimination and gustatory thresholds in captive-born frugivorous Old World bats. Mammalia 64:135-143.

HLADIK, A. \& HLADIK, C. M. 1969. Rapports trophiques entre vegetation et primates dans la forêt de Barro Colorado (Panama). Terre et Vie 23:25-117.

HLADIK, C. M. \& SIMMEN, B. 1996. Taste perception and feeding behavior in nonhuman primates and human populations. Evolutionary Anthropology 5:58-71.

HOLDRIDGE, L. R., GRENKE, W. C., HATHEWAY, W. H., LIANG, T. \& TOSI, J. A. 1971. Forest environments in tropical life zones: a pilot study. Pergamon Press, Oxford. 747 pp.

JANSON, C. H. 1983. Adaptation of fruit morphology to dispersal agents in a Neotropical forest. Science 219:187-189.

JANSON, C. H., STILES, E. W. \& WHITE, D. W. 1986. Selection on plant fruiting traits by brown capuchin monkey: a multivariate approach. Pp. 82-92 in Estrada, A. \& Fleming, T. H. (eds). Frugivores and seed dispersal. Dr W. Junk Publishers, Dordrecht, The Netherlands.

JOHNSON, R. A., WILLSON, M. F. \& THOMPSON, J. N. 1985. Nutritional values of wild fruits and consumption by migrant frugivorous birds. Ecology 66:819-827.

KO, I. W. P., CORLETT, R. T. \& XU, R.-J. 1998. Sugar composition of wild fruits in Hong Kong, China. Journal of Tropical Ecology 14:381-387.

KORINE, C. E., KALKO, K. V. \& HERRE, E. A. 2000. Fruit characteristics and factors affecting fruit removal in a Panamanian community of strangler figs. Oecologia 123:560-568.

LASKA, M. 1997. Taste preferences for five food-associated sugars in the squirrel monkey (Saimiri sciureus). Primates 37:93-97.

LASKA, M., CARRERA-SÁNCHEZ, E., RODRÍGUEZ-RIVERA, J. A. \& RODRÍGUES-LUNA, E. 1996. Gustatory thresholds for foodassociated sugars in the spider monkey (Ateles geoffroyi). American Journal of Primatology 39:189-193.

LASKA, M., CARRERA-SÁNCHEZ, E. \& RODRÍGUEZ-LUNA, E. 1998. Relative taste preferences for food associated sugars in the spider monkey (Ateles geoffroyi). Primates 39:91-96.
LASKA, M., SCHEUBER, H.-P., CARRERA-SÁNCHEZ, E. \& RODRÍGUEZ-LUNA, E. 1999a. Taste difference thresholds for sucrose in two species of nonhuman primates. American Journal of Primatology 48:153-160.

LASKA, M., SCHÜLL, E. \& SCHEUBER, H.-P. 1999b. Taste preference thresholds for food-associated sugars in baboons (Papio hamadryas anubis). International Journal of Primatology 20:25-33.

LASKA, M., HERNANDEZ-SALAZAR, L. T., RODRIGUEZ-LUNA, E. \& HUDSON, R. 2000. Food preferences and nutrient composition in captive spider monkeys, Ateles geoffroyi. International Journal of Primatology 21:671-683.

LASKA, M., KOHLMANN, S., HERNANDEZ-SALAZAR, L. T. \& RODRÍGUEZ-LUNA, E. 2001. Gustatory responses to polycose in four species of non-human primates. Folia Primatologica 72:171172.

LEE, Y. C. 1990. High-performance anion-exchange chromatography for carbohydrate analysis. Analytical Biochemistry 189:151-162.

LEIGHTON, M. 1993. Modeling dietary selectivity by Bornean orangutans: evidence for integration of multiple criteria in fruit selection. International Journal of Primatology 14:257-313.

LEVEY, D. J., MOERMOND, T. C. \& DENSLOW, J. S. 1994. Frugivory: an overview. Pp. 282-294 in McDade, L. A., Bawa, K. S., Hespenheide, H. A. \& Hartshorn, G. S. (eds). La Selva: ecology and natural history of a neotropical rain forest. University of Chicago Press, Chicago.

LUCAS, P. W., BETA, T., DARVELl, B. W., DOMINY, N. J., ESSACKJEE, H. C., LEE, P. K. D., OSORIO, D., RAMSDEN, L., YAMASHITA, N. \& YUEN, T. D. B. 2001. Field kit to characterize physical, chemical and spatial aspects of potential foods of primates. Folia Primatologica 72:11-15.

MARTÍNEZ DEL RÍO, C. \& KARASOV, W. H. 1990. Digestion strategies in nectar and fruit eating birds and the sugar composition of plant reward. American Naturalist 136:618-637.

MARTÍNEZ DEL RÍO, C. \& RESTREPO, C. 1993. Ecological and behavioral consequences of digestion in frugivorous animals. Vegetatio 107/108:205-216.

MARTÍNEZ DEL RÍO, C., BAKER, H. G. \& BAKER, I. 1992. Ecological and evolutionary implications of digestive processes: bird preferences and the sugar constituents of floral nectar and fruit pulp. Experientia 48:544-551.

MILTON, K. 1981. Food choice and digestive strategies of two sympatric primate species. American Naturalist 117:496-505.

NELSON, G., HOON, M. A., CHANDRASHEKAR, J., ZHANG, Y., RYBA, N. J. P. \& ZUKER, C. S. 2001. Mammalian sweet taste receptors. Cell 106:381-390.

NEWSTROM, L. E., FRANKIE, G. W., BAKER, H. G. \& COLWELL, R. K. 1994. Diversity of long-term flowering patterns. Pp. 142-160 in McDade, L. A., Bawa, K. S., Hespenheide, H. A. \& Hartshorn, G. S. (eds). La Selva: ecology and natural history of a neotropical rain forest. University of Chicago Press, Chicago.

PALMEIRIM, J. M., GORCHOV, D. L. \& STOLESON, S. 1989. Trophic structure of a neotropical frugivore community: is there competition between birds and bats? Oecologia 79:403-411.

QUESADA, F. J., JIMÉNEZ, Q., ZAMORA, N., AGUILAR, R. \& 
GONZÁleZ, J. 1997. Arboles de la Peninsula de Osa. Instituto Nacional de Biodiversidad. Heredia, Costa Rica. 411 pp.

SCLAFANI, A. 1991. Starch and sugar tastes in rodents: an update. Brain Research Bulletin 27:383-386.

SIMMEN, B. \& SABATIER, D. 1996. Diets of some Guianan primates: food composition and food choices. International Journal of Primatology 17:661-692.

SKUTCH, A. F. 1980. Arils as food of tropical American birds. Condor $82: 31-42$.

STILES, G. F. \& SKUTCH, A. F. 1989. A guide to the birds of Costa Rica. Cornell University Press, Ithaca. $511 \mathrm{pp}$.

SYSTAT 1998. Systat 9.0 for Windows. SPSS Inc., Chicago.

WENDELN, M. C., RUNKLE, J. R. \& KALKO, E. V. 2000. Nutritional values of 14 fig species and bat feeding preferences in Panama. Biotropica 32:489-501.
WHEELWRIGHT, N. T. \& ORIANS, G. H. 1982. Seed dispersal by animals: contrast with pollen dispersal, problems of terminology, and constraints on coevolution. American Naturalist 119:402-413.

WITMER, M. C. 1998. Ecological and evolutionary implications of energy and protein requirements of avian frugivores eating sugary diets. Physiological Zoology 71:599-610.

WORTHINGTON, A. 1990. Comportamiento de forrajeo de dos especies de saltarines en respuesta a la escasez de frutos. Pp. 285-304 in Leigh, E. G., Stanley, R. \& Windsor, D. M (eds). Ecologia de un bosque tropical: ciclos estacionales y cambios a largo plazo. Smithsonian Tropical Research Institute, Panama.

WRANGHAM, R. W., CONKLIN, N. L., ETOT, G., OBUA, J., HUNT, K. D., HAUSSER, M. D. \& CLARK, A. P. 1991. The value of figs to chimpanzees. International Journal of Primatology 14:243-256. 